\title{
'Land as a womb': Impact of gender imbalances on land redistribution in the Third Chimurenga
}

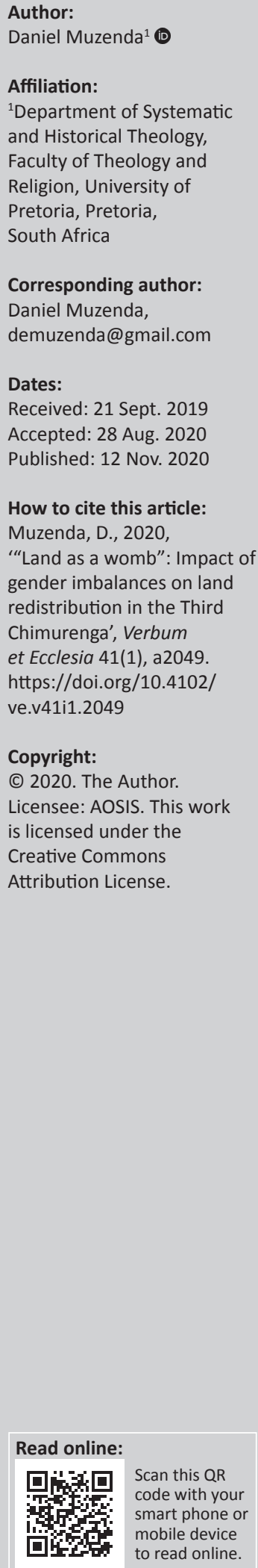

This theoretical article analyses the impact of gender imbalances in land redistribution in Zimbabwe's Third Chimurenga. The article argues that if land is a womb, why is that women who are the mothers are sidelined and undermined in land redistribution in postcolonial Zimbabwe. The article also highlights the importance of land which led to a group of 90 women scaling the highest mountain in protest of land imbalances on the basis of gender. History has it that many people were displaced, uprooted and some even killed because of land issues. In this struggle for land, there is always a section of society which is undermined and pushed to the periphery when it comes to the use and ownership of this valuable resource. Land is the centre of reproduction and production in Zimbabwe. It gives people their sense of belonging and identity. Women in the Third Chimurenga sang, danced and gave moral support but the land tenure systems prohibit them to own land outside male or patriarchal dominance. In this article, I demonstrated the impact of gender imbalances on land redistribution in the Third Chimurenga by highlighting the power of a group of women who scaled the highest mountain in Zimbabwe, Mount Nyangani, to challenge the land tenure systems that oppress women so far as land ownership is concerned. The article engages the black liberation theological paradigm to show the irruption of women into the sacred space dominated by the male.

Interdisciplinary and/or interdisciplinary implications: This article is interdisciplinary in the sense that it cuts across disciplines as it addresses issues of land, gender, patriarchy and a liberation theology which reflect the need for human emancipation, especially the oppressed groups.

Keywords: land; gender; patriarchy; Chimurenga; Zimbabwe.

\section{Introduction}

This article looks at the discourse of women empowerment that has grown swiftly in the past two decades as women move up in various ways within different domains of life. Gender equality has been at the centre of debate in Zimbabwe, Africa and globally for many years, with women attacking gender prejudice. This gender prejudice has made a negative impact on women as they are left out of development and other critical social economic enhancement because they are women. This kind of stereotype has made women inferior to men, including their own sons, thus impacting negatively land tenure system in Zimbabwe. The male-dominated society has facilitated a serious gender imbalance on land.

Gender imbalance continues to cast its dark shadow on how land was redistributed during the Fast Track Land Reformation. This article gives insights into how women are challenging the redistribution of land in Zimbabwe during the Fast Track Land Redistribution (Jambanja) or Third Chimurenga. This was a radical repossession, when black people took over land from white farmers, amending policies and laws to effect the repossession (Matondi 2012:1). The women challenged the land redistribution by scaling the highest mountain in Zimbabwe. If really land is a mother or womb, why is it that women were sidelined yet land is a symbol of motherhood? To say land is a womb simply means that land is a source of life (Vellem 2016). If land is like a mother for the VaKaranga, the issues of women must be taken seriously and evaluated in the Third Chimurenga.

\section{Definition of gender}

Sifuniso et al. (2000:2) define gender as the social meanings ascribed to being either a man or a woman in a given society and the expectations held as to the character, attitude and behaviour. Gender, unlike sex which is biological, is socially constructed. Gender influences the different 
behaviours, roles, responsibilities, identities and treatment of men and women in society. Gender depends on the culture and history of a particular society and differs from one culture to another.

\section{Theories of gender differences}

Scholars and philosophers of different disciplines have invested much time and thought on efforts to understand and explain the differences between men and women worldwide. Various theories have been constructed and, amongst them, most central ones are the gender constructionist theory and the biological determinism/essentialism theory. This article will focus on the social construction of gender which has been used by the society to oppress and subjugate women.

\section{Social construction of gender}

The social construction theory argues that gender behaviour is not innate but is socially constructed. It is based on the concept of gender socialisation, which 'refers to the means whereby social expectations regarding gender appropriate characteristics are conveyed. These expectations are often based on stereotyped beliefs' (Dekker \& Lemmer 1993:9). It has a dual significance for children, that is, it provides them with models for present behaviour and it prepares them for adult life (Dekker \& Lemmer 1993:9).

The social construction theory of gender stresses that boys and girls are not born men and women but learn to be masculine and feminine in conformity with social values and practices. Young boys and girls learn the appropriate behaviour for their sex during primary socialisation in the family and secondary socialisation at school, at church and amongst their peers.

Dube (2003) shares the same sentiments by affirming that gender is socially and culturally constructed. It refers to how individuals are brought up to act as men and women. In other words, whilst one's sexual identity as a male or female is a biological fact, how one expresses the masculinity and/or femininity is shaped by societal values and norms. Elaborating that gender is socially constructed, Dube (2003:86) draws the following conclusion: gender is not natural, is not divine, has to do with social relationships and men and women can be reconstructed and reformed by the society and since it is culturally constructed, it can be socially deconstructed. Human agents are at the forefront in terms of gender construction, which expresses the marginality and invisibility of women as both subjects and objects in the study of religion.

Butler (1990:ix) introduces the concept of the elasticity of gender perceptions arguing that, all identity categories, including gender, are in fact the products of institutions, practices and discourses. According to Butler (1990), individuals are not locked up in anatomy, with no room for manoeuvre but have the capacity to challenge biological deterministic or essentialist stereotypes used to give them identities. Some have even given the examples of heterosexuality versus homosexuality. If biology says a man must be attracted to a woman, and yet some men are attracted by men, then the essentialism of biology as a central identity determinant becomes questionable. Homosexuality defies the explanatory logic of biological determinism and so does trans-sexuality.

The social construction of gender is therefore the social making of gender through the process of gender socialisation. The social institutions that are responsible for gender construction are called socialisation forces like the family, school, media, language, music and religion, amongst others (Haralambos \& Holborn 2004). The people who carry out the socialisation are socialisation agents, such as parents, teachers, pastors, peers and many others. Some institutions like the family are primary socialisation institutions in the sense that they are the first that any child comes into contact with. Murdock (cited in Haralambos \& Holborn 2004) says that the family is the child's first window to the world and no other gender socialisation institution rivals it in gender socialisation. Such prime gender socialisation institutions are called primary socialisation forces, whilst those institutions that the child comes in contact with after primary socialisation are called secondary socialisation forces, such as the school, peer group and others. Both the primary and secondary forces create, reinforce, maintain and perpetuate gender differences, but the primary forces are the chief creators, whilst the secondary forces are the chief maintainers, reinforcers and perpetuators.

The theory of gender socialisation is criticised for denying individual choice or free will by portraying individuals as over-socialised and passively conforming to predetermined social roles. Individuals cannot dare to actively amend, recreate or redefine social roles in a reflective and purposeful way. It is therefore a deficit model, where difference is seen as deviance or abnormality. It emphasises role modelling to provide messages about gender behaviours, which are allegedly passively soaked up by boys and girls.

Some scholars like Connell (2000) have argued that the gender socialisation theory is so confusing for it relies on biological distinction which leaves it with a non-social conception of the basis of difference between men and women. Walby (1999) also states that the theory does not fully explain where the specific and differentiated contents of gender roles come from and whose interests they represent. Haralambos et al. (2013) contend that there is deficiency in the theory in explaining the existence of feminists, lesbians and other people who are not like the stereotype for their sex is inadequately explained by this theory as failed products of socialisation. It justifies patriarchal oppression of women through the socialisation process.

The categories of man and woman have no universal explanatory force that goes much beyond strictly physiological. Gender roles are culturally produced. Whatever the biological differences between men and women, it is the culture of society that exerts most influence on the creation of masculinity 
and femininity behaviour. Gender is socially constructed in the sense that the behaviour of men and women is learnt rather than being an inevitable result of biology (Haralambos et al. 2004:101). The VaKaranga society's socialisation of boys and girls is different. Boys from a very tender age are taught to be tough and endure pain in silence. If a boy cries, he is likened to a woman. The common idiom amongst the VaKaranga men is kufa kwemurume hubuda ura, which literally means that until or unless your intestines are ripped out you are still alive to do something as a man. Moreover, when a man wants to try something new, you could hear most of the VaKaranga men saying chemurume chivindi, chemukadzi ibapu. This implies that man must have courage whilst women are regarded as cowards.

In Zimbabwe, the Ministry of Women's Affairs failed to incorporate former women combatants and guerrilla as most of them lacked advanced formal education qualifications. As a result, their militancy and devotion to revolution change were not harnessed. Many of these women combatants faced serious challenges in being reabsorbed into society. Their experience as guerrillas was not readily welcomed by the society and some parents vetoed the idea of their sons marrying these former guerrillas who were seen as wild and stubborn largely because of their self-assertion (Maloba 2007:156).

A woman is understood as a creature that has been made, fabricated and moulded to social purpose. For example, in marriage, the social structuring of marriage necessitates appropriate training for those who are to fill its requirements. It must be obvious then that acquirement of certain characteristics had been rendered inevitable for women in general. What is significant in this development is that such a social construction is purported to be based on the real nature of women, a nature that is claimed to be remarkably consistent even in the presence of very difficult circumstances but that women are compelled to conform. Prevailing social standards in society present morally accepted behaviour of a woman which is not actually according to the woman herself, but a code of manners formulated in the interest of her master (Cleveland, Stokdale, Murphy \& Gutek 1988). Even the behaviour of woman in the VaKaranga tradition follows certain pathways agreed by men in their council (dare).

As women continue to fall victims of moral construction by others, especially male dominance, they are rendered incapable of true morality. Women live therefore by secondhand virtues, a situation made even more demeaning by the reduction of all of these to one virtue of honour. The women's attempts to conform freely and rationally to standards set by others should be further distilled into a statement about the physical state of her body, which is the final insult and contradiction. The woman is rendered powerless in her personal and social life by this reduction. The life of a woman is thus determined by the requirements of social institutions which she had no part in formulating and the virtue of life is judged accordingly (Cleveland et al. 1988).

\section{The church and gender}

The majority of religions in the world subordinate women. In an Islamic tradition, it is argued that a devout Muslim would cease to pray when a strange woman or a donkey appears (Acker 1997). A prayer by a devout Jew reads, I thank God that I am a Jew and not a gentile, am a man and not a woman. In Christianity, the creation story shows that the woman was not formed from the dust of the earth but was taken from the rib of Adam. Adam was given dominion over creation and a man is the head of the family as Christ is also the head of the church. In traditional religion, women do not speak to the ancestral spirit [midzimu] but can talk to stray spirits [mashavi]. Women do not make important religious decisions in the families. They cannot appease angry ancestral spirits for they do not belong to them but it is the responsibility of the fathers, brothers or brother's children to do the same.

The Imago Dei [image of God] does not refer to God's creation of two gendered beings, but to the creation of complex human beings who can relate to one another in a great variety of ways once they are freed from adherence to dualistic categories that have been elevated to a supernatural apriority. In this way also, the notion of the complementarity of man and woman, which relies on an equality that attempts to deny the image of God, can be exposed and superseded (Parson 1996:230).

Chitando (2009) argues that apart from academic contributions, more work remains to be done if the church in Zimbabwe is to transform Christianity into a truly African religion. A useful starting point is the refashioning of ecclesiology to reflect the post-colonial dispensation. Gender recognition of the roles of women as well as facilitating their occupation of leadership roles is also crucial. The old age male monopoly of African church power requires critical analysis. The Methodist Church in Zimbabwe is a practical example where more than $60 \%$ of its membership constitutes women, but of the nine bishops they have only one is a woman.

Issues of class and gender discrimination are very controversial and it seems that the church has aligned itself with the forces of gender oppression. The church sometimes finds ways of justifying the oppression of women and other minorities. The church in Africa must come of age and stop discharging finished products of Eurocentric theology packaged well in European ecclesiology (Oduyoye 1995:18). This dependence on Eurocentric models and hopes is no substitute for the church to work out its own models of salvation in a particular history and culture.

Our contemporary language has created a mindset in which men and women are rigidly opposed to each other and our religious myths show a bias towards rigid limits for women and mobility for men. The portraits of women in African mythology serve as models for women's being that is what any woman or all women ought to be. A woman is simply a human being and she does not have to prove that her way 
being is as human as that of a man and her destiny as a mother is not derived from a man's destiny (Oduyoye 1995:18).

Acceptance to Christianity demands not only a break with the traditional religious system but also an abandonment of the African cultural background. The harvest amongst older people was discouraging. Richard Sykes, the Jesuit missionary, said in this regard, 'the man who had plurality of wives is practically hopeless as a prospective Christian convert. The hope lies with the children' (Chitando 2009:6).

Mukonyora (2007) has argued that whilst both the traditional religion and Christianity marginalised women, it is possible to recover a feminine dimension of the Mwari religion. She maintains that Zimbabwean women can read the Bible, with their own eyes and this affects their liberation from patriarchal oppression. L. Dube Chirairo has described the centrality of women prophet in tackling problems that emanate from the Shona world view. For Dube (1990), the issue of gender is visible in its absence. Women in the colonised space not only suffer from the yoke of colonial oppression but also endure the burden of patriarchy.

\section{Women and the struggle for land}

In Zimbabwe, the most famous woman in the struggle against colonialism was Nehanda Nyakasikana, a spirit medium who took a leading role in channelling resistance to the settlers. The settlers, military and administrators, who were coming from England where the domestication of women particularly amongst the bourgeoisie was advanced were dumbfounded by the unexpected role Nehanda played in the resistance. They explained it by saying that she was a witch with some kind of power over men of her nation, and hence her bizarre behaviour and the men's cooperation with her. Nehanda's involvement in the anti-colonial struggles is an indication of the space which existed for women in precolonial Shona society in the religious-political ream at a time when the distinctions between politics, religion and production were not pronounced. Nehanda was not a maternal symbol and as the medium of a powerful spirit, her spiritual political identity overshadowed her identity as a woman.

Many people suffered and died during Zimbabwe's war of liberation and many accounts of that struggle have been written; however, the story of women, the wives and mothers who remained behind this struggle has not yet been told. The stories reveal courage, endurance, humour and wisdom. These women, the mothers, are both victims and actors. Throughout the war, and over again they fed and protected the freedom fighters and they risked their lives to do so. The men were around but used to command these mothers to hurry with food before they were beaten up by the freedom fighters. Without these women, the war could not have been won (Staunton 1991:xi). This context of women struggling for freedom and giving moral support to the struggle for land makes them ideal candidates for land ownership.

\section{Land as an important resource}

Land has always been the source of life in Africa. African history shows that the African life is based on land. It is the land that produces which is needed for human consumption. The value and importance of land in Africa are demonstrated by the fact that from ancient to modern history, land always caused wars and political and social disturbances whenever it was not equally distributed amongst people.

The common practice in Africa has been that land has always been entrusted to the chief as the main distributor. The chiefs also had the mandate to address conflicts over land although favouritism could not be ruled out. In pre-colonial Africa, the chiefs made sure that every person in the tribe or nation and clan had some land to produce food which is the basic human need, except in matrilineal societies where property such as land is handed down from mother to daughter. With the impact of colonialism, the concept of land and its distribution changed drastically. Colonialism basically became more pronounced in Africa in the 19th century. By this time, life in Europe and the rest of the western world had drastically changed from the feudal system where land was a source of life to many people in the rural areas for developing towns and cities. The majority of the people were completely isolated from land ownership. The decline in land ownership became the new custom of the western people.

This is the situation and attitude which many westerners brought to Africa under the sphere of colonialism. Africa was divided between major European countries and the major aim was to take away land from the majority of the people to be accumulated in the hands of some few white people. This was characterised by driving away of indigenous people off their lands and creating big farms owned by white settlers. This marked the beginning of poverty in Africa. It is unfortunate that even Christian missionaries who claimed to have brought the Good News also took part in this accumulation of land.

In traditional African thought, land was perceived as a communal property and largely each tribal group enjoyed an exclusive ownership of the same land. Within these tribal groups, parents would automatically pass the same land rights to their children and to their children's children. For traditional Africans, land was not only $t$ a commercial commodity but also a sociocultural and spiritual asset that was shared and controlled within communities. Land was inextricably intertwined with the ontological beliefs of Africans.

Amanze (2002:304) observes that in the African set-up, people perceive themselves as simply trustees for the land that God has entrusted them with, for the use of the whole community. No one, including chiefs, had the right to sell land as a commodity. The community includes the ancestors, the living themselves and the future generation of that particular society. African land was not sold because it did not belong to 
an individual, that is, it was a communal asset. Land was highly esteemed as a source of all life. The globalised ownership of land comes with modernity. Globalisation comes with many advantages but some serious disadvantage to that at the lowest level of the economy. This is particularly true in the area of land ownership. Poor persons, who could not have much in their name, would have land which might be the only asset they would pass to their children as inheritance.

There are serious gender imbalances with regard to land. As argued by Chitando (2013), women remain marginalised in terms of land ownership and that even increases their vulnerability to human immunodeficiency virus (HIV) as they sometimes resort to survival strategies that can compromise their health. Land is a critical resource that women are denied access to and in many instances women's control of land is linked to their relationship with men (Chitando 2013:6).

For the VaKaranga people, the access to land was mostly guaranteed to women upon bearing male children. Male children are perceived as an extension of lineage [zita harifaniri kurova], meaning that there must be a perpetuation of the clan's name. Divorce for the VaKaranga is an easy task provided that there are no male children and this can also justify polygamy. The VaKaranga cultural fabric prohibits women to 'inherit' land outright except in circumstances where through the dispensation of their fathers or male relatives. This could be in situations of a divorced daughter or where the daughter is unable to marry.

One of the most obvious structural features of the biblical patriarchal family is its location of woman within the role of motherhood. A woman is a child bearer. This role is marked out as primary if not the only legitimate place of women. It is the place where a man can risk a woman having some freedom, power even but still within the formal constraints of male authority. Not surprisingly, despite many dimensions of women's lives that could frame their stories, the narrow focus on women as mothers far and away predominates. But despite attempts to monopolise power systematically, the ability to effect change does not wholly lie within the grasp of men (Sawyer 1995). From the view point of men who want big families for the sake of productivity (more hands to work in the farm), protection (safety in numbers) and prestige (as a sign of virility and prosperity, and thus power), motherhood is an easily exploited role. Lobola or roora in karanga not only legitimises the marriage but also gives the husband legal custody and dominion over the wife and the children resulting from that union.

If land is a womb or mother, its cultural symbol is very important for the Vakaranga, which also means that its ownership and use must be a perquisite for all people regardless of gender (Bakare 1993; Vengei 2013). Land in this article is a source of life and that women are the ones who are at the centre of taking care of the family, it entails that without land their task is an uphill one.

\section{Scaling Mount Nyangani to be heard}

Any strategy to achieve greater power must be accompanied by voicing for if women do not deliberately attempt to break their silence about their situations, others will continue to maintain it. Dealing justly with African women must begin with taking seriously women's questions and concerns about their status. Trivialising women's concerns do far more harm than good. Women's voices should be listened to when they speak about the God-ordained dignity of every human person or the consequent need of each person for respect. To expect women to uphold all that is humanising in African culture and yet deny their participation in the politics of family and nation is like asking them to make bricks without straw (Oduyoye 1995:171).

There has always been a patriarchal construction of land in Zimbabwe. Possession and land ownership of land are traditionally a symbol of a man and his wealth. Women in the rural areas have no access to land because it is believed that they do not belong to the family they are married to, they remain outsiders. Even when one is not yet married as a daughter, sister or an aunt, they did not own land but rather the land belonged to their brothers, uncles and fathers. Even under the third Chimurenga, it is argued that women were not prioritised in terms of land allocation which was distributed to male households.

Goebel (2005:37) argues that in Zimbabwean context, women's lack of primary land rights was historically underpinned by the definition of their legal status as minors and the dual legal system practised by most African women under the dictates of customary law in the colonial period. After independence in 1982, the legal age of majority recognised women by granting them majority status at the age of 18 . Whilst women were recognised under the majority status at the age of 18 , the customary law continued to cast its dark shadow on women's access to land in communal areas. Women continued to have access to land through accepted customary law systems, such as marriage and bearing male children. Even under the unfortunate circumstances of death, widows could not inherit the land. Those widows with male children will only keep the land in trust for the male heir, usually the eldest son. Many a times, this led to the eviction and dispossession of widows from the land they shared with their husbands.

Women were thus left absolutely landless, yet were the ones who mostly needed land to provide for the family. The allocation of land to men left women with little access or no space for them to provide for the family without access to land. Many civic and human rights organisations in Zimbabwe are fighting for the rights of women in all spheres of life, of which land is one of them. But there are still a great numbers obstacles at the community level, hindering women from having full access and ownership of land. Moreover, the legal framework is also shifting towards accommodating women but it is just on paper, whilst on the ground a different story is presented and portrayed. Even under the government 
resettlement policies, women have been left vulnerable. One can rightly argue that gender analysis of the land in Zimbabwe shows the inability of the general law to ensure women's rights to land when such laws are not socially legitimate and enforceable.

The lack of land pushed women to urban areas where they hoped they would make a living much better than the communal life. This resulted in many women finding the situation in town and cities difficult and unsustainable. Some were forced in commercial sex work, whilst others embarked on cross-border trading.

The gender imbalances in terms of land allocation and ownership in the Third Chimurenga resulted in women scaling the highest mountain in Zimbabwe, Mount Nyangani, which is located in the Manicaland province about $275 \mathrm{~km}$ north-west Mutare (http://www.herald.co. $\mathrm{zw})$. They scaled the mountain for them to be heard in as far as land ownership was concerned. Their motive for going up Mount Nyangani was to raise their concerns to both the traditional and government leadership on the inequalities over land redistribution, which sidelined women as compared to their male counterparts (http://www.herald. co.zw). It was a group of 90 women from different socioeconomic and religious backgrounds.

The scaling of Mount Nyangani can be equated to what Tamez (1989) referred to as the irruption within the irruption. The irruption of women in church and society is an integral part of the voice of the earth's voiceless majority that is beginning to penetrate the atmosphere and disturb the peace of the principalities and powers that hold the structure of our so-called one world in their hands. Moreover, Tamez (1989:43) asserts that the irruption of history into the lives of women is the irruption of historic realisation into the lives of millions of women who have been silent for a long time. This leads them to the liberation struggle by way of an active involvement at different fronts from which they had previously been absent. Their presence is like as if a strong wind is blowing opening eyes and loosing tongues. There are also shifting stances and enabling arms to reach out to new embraces and hands to take up other tools, impelling feet to take other steps and raising the voice so that its song and its lament might be heard. Woman begins to take her place as an agent of history (Tamez 1989:43).

Women's agency is of course exerted within particular structures of power. Certain institutions and opportunities enable women to challenge and transform repressive gender norms, whilst others constrain what women can do. National courts in both colonial and contemporary Zimbabwe provided an important venue for demanding change in betrothal, marriage, divorce, child custody, inheritance and property rights (Hodgson \& McCurdy 2001:14).

Chief Samhembere confirmed that it was possible for the traditional leadership to give equal opportunities to both men and women. The traditional leadership through Chief
Samhembere pledged its support to the women's complaints and alluded to the fact that it was high time that Zimbabweans appreciate the important role played by women in the community and that they deserve better treatment in as far as land was concerned. There was no problem with women owning land in the community (Zvayi 2016). This shows the extent at which the scaling of the mountain impacted society. Chiefs as custodians of the land were the major obstacle in as far as land allocation to women was concerned.

In groups, women have challenged the injustices perpetuated by the colonial and postcolonial states, and created new economic and social space for themselves. They have fought sexist barriers to employment, established formal political association and pursued financial autonomy in the face of mounting hostility. Women have slightly succeeded in reconfiguring the gendered order in which they live (Hodgson \& McCurdy 2001:2). The VaKaranga women have turned the tables upside down by demanding their voices to be heard through different channels. Some have written on the walls of their huts, scorch cats and wheel barrows the inscription musha mukadzi, literary meaning 'the home is a wife'. This shows how serious women are moving towards gendered change. They write the musha mukadzi even those who are married, showing that the centre no longer holds.

An analysis of the above incident of women scaling the highest mountain pick in Zimbabwe shows how these women were prepared to transform land imbalances that were created by the Jambanja project. The women chose the highest mountain but not any other mountain and this mountain is a sacred mountain where stories of human disappearance are always narrated and manifestations of hierophanies, but the women braved all these and reached the pick for their voices to be heard. It was a clear demonstration that women were not weak as society portrays them and that what men can do women can also do and even much better.

The VaKaranga men believe that women cannot even climb a tree let alone a mountain. Scaling of mountains is a male activity. Anything which is associated with scaling [kukwira] is a male arena. In the VaKaranga society if you marry a wife who can climb a tree, they say you have married a man [wakaroora murume chaiye] let alone the mountain. On the VaKaranga dare/indaba, that is, council, the word kukwira is not ordinary for it means quite a lot. Kukwira may mean 'dominating' or may mean 'having sex'. On the dare/indaba, they would ask wakamukwira here, meaning 'did you have sex with her?' The fear of the VaKaranga men is to see women dominating a male reserved area; therefore, when women scaled Mount Nyangani, some men felt threatened because it is always men who must be on top even when doing sex.

Following the theory that for the liberation of all, the most oppressed subject needs to be liberated, and Aquino \& Thau (2009) asserts that the most oppressed individual is the 
impoverished woman. She argues that aside from being exploited because of her class (and possibly her race), the destitute woman is additionally exploited, oppressed and treated as an inferior not only in society but also in her own community because of her sexuality and gender.

Women also argued that land was the reason some of them had to be involved in the liberation struggle alongside their male counterparts. They argued that during the liberation struggle, there was no gender classification, hence the same policy should be observed in land redistribution (http:/ / www.herald.co.zw). The civic society also joined the cries of women for land imbalances. The civic society challenged the authorities to consider gender justice in land ownership.

Statistics reveal that of the $70 \%$ of the women population in rural areas, only $18 \%$ of women benefited on the small-scale farms called A1 and 12\% under the large-scale commercial farms known as A2. This shows the extent to which women trail in land ownership. The protests by women were validated by the constitution which supports equality on all frontiers (http://www.herald.co.zw). According to Section 17 (1) (c) of the constitution (amendment 20 of 2013):

$[T]$ he State and all institutions and agencies of government at every level must take practical measures to ensure that women have access to resources including land, on the basis of equality with men. (p. 20)

This section of the constitution has proved to be just an inscription which does not have great impact on the country as is reflected by the land imbalances in the distribution of land in the Third Chimurenga.

The scaling of Mount Nyangani by women shows the importance of land for sustainability and how women are challenging patriarchal ownership of land. This radical view by women has left men who are the custodian of patriarchal systems challenged, whilst at the same time it has also challenged other women who have for a very long time remained willing participants in patriarchal systems of land ownership. It was a kairos moment for both women and men.

\section{Security of tenure for women}

The legal framework on access and utilisation of land by women does not guarantee them security of tenure. Women in most cases have to access land through male heads of household, such as husbands, brothers or fathers. This dependence on men makes possible the abuse of women as their use of land depends on the continuation of their relationship with these men (http://www.idrc.ca). For married women, this permits their husbands to exploit their labour. Thus, during the tobacco and cotton selling season, we have men who work in towns taking control of the produce produced by their wives and children in rural areas. In some cases, significant abuse is reported emanating from the sale of these produce to the detriment of the women and some women have committed suicide sighting abuse of their labour. The traditional view of the VaKaranga on land is that land belongs to man. It is a patriarchal domain to the extent that even women in marriage are allocated a piece of land by their husbands known as a tsevu. Tsevu for the VaKaranga is a piece of land allocated to a wife by the husband for purposes of cultivating crops associated with women, such as groundnuts [nzungu], round nuts [nyimo] and other small crops. This tsevu is not permanent because it can be changed at will by the husband and another tsevu can be allocated. Husbands usually do not work on the tsevu for it is a woman's domain and because of pride and dominance they shun the tsevu and work on the main stream farm. In some cases, the woman has to endure more extra time by working first on the main farm and then going to the tseou. As a Mukaranga man I only remember my mother having a small tsevu where she used to work extra time. This tsevu was her only possession as far as a land is concerned. After the death of my father, my elder brother was given the title of the land and my mother again would be allocated the tsevu by my brother who had taken ownership, including allocating another tsevu to his own wife. This shows the extent to which women are deprived of land ownership in a patriarchally dominated VaKaranga tradition. This implies that land is for the male members of the community.

For single women who never married, the failure to allocate them land in their own right in communal areas means putting them at the mercy of their fathers, brothers and other male figures with power and influence. Moreover, divorced women are also another class of women who find it difficult to access land on the premise that land is accessed through marriage. It is a VaKaranga tradition that a divorced woman must be sent back to her maternal home and be supported by her father and brothers who may as well be hostile to her.

\section{Conclusion}

The scaling of the highest mountain by women in order for their voices to be heard shows the importance of land as a source of social, economic and political power in Zimbabwe. It also entails that the centre can be challenged and this centre is patriarchy which gives more latitude to men in land ownership. This article also unearthed the close and fluid relationship between patriarchy and empire in that the two seem to be borrowed concepts for VaKaranga people. Whilst there is male dominance in the VaKaranga communities, it was not legalised as was done by colonial settlers; hence, women are fighting a double-edged sword that is empire and the elite class which were transferred power by the empire. It also speaks about the shortcomings of the Third Chimurenga in the sense that women did not benefit as their male counterparts did in this process. Whilst women constitute $52 \%$ of the total population in Zimbabwe, only $12 \%$ are benefited from the A2 commercial farms and 18\% are benefited from the small-scale farm, a percentage far below the expectations of women.

The above percentage which is below the expectations of women made them realise that without protesting the system of patriarchy, they will remain disempowered. 
Women have demonstrated that they are agents of social change as the scaling of Mount Nyangani sent shock waves to patriarchy not only in the social ordering of the society but also to the church which is also an embodiment of patriarchy through inherited Standing Orders and Books of Discipline.

Black theology must reflect critically on itself, assisting itself to rethink, reimagine and reconstruct itself in ways that could address not only issues of race and class but also issues of gender oppression. The stance taken by women is a challenge to black liberation theology from any possible complacency there might be or any self-congratulatory possibility and face its complicity in gender oppression. Black liberation theology is not only limited to issues of oppression of men but it must embrace a holistic approach to issues of oppression.

\section{Acknowledgements Competing interests}

The author has declared that no competing interests exist.

\section{Author's contributions}

I declare that I am the sole author of this research article.

\section{Ethical consideration}

This article followed all ethical standards for a research without direct contact with human or animal subjects.

\section{Funding information}

This research received no specific grant from any funding agency in the public, commercial or not-for-profit sectors.

\section{Data availability statement}

Data sharing is not applicable to this article as no new data were created or analysed in this study.

\section{Disclaimer}

The views and opinions expressed in this article are those of the author and do not necessarily reflect the official policy or position of any affiliated agency of the author.

\section{References}

Acker, S., 1987, 'Feminist theory and the study of gender education', Internationa Review of Education 33(9), 419-435. https://doi.org/10.1007/BF00615157

Amanze, J.N., 2002, African traditional religions and culture in Botswana: A comprehensive textbook, Pula Press, Gaborone.

Aquino, K. \& Thau, S., 2009, 'Workplace victimization: Aggression from the target's perspective', The Annual Review of Psychology 60, 717-741. https://doi. org/10.1146/annurev.psych.60.110707.163703

Bakare, A.S., 1993, My Right to Land: In the Bible and in Zimbabwe. Zimbabwe Council of Churches, Harare.

Butler, D. \& Geis, F.L., 1990, 'Nonverbal affect responses to male and female leaders: Implication for leadership evaluations', Journal of Personality and Socia Psychology 58(1), 48-59. https://doi.org/10.1037/0022-3514.58.1.48

Chitando, E., 2009, Troubled but not destroyed, WCC Publications, Geneva.

Chitando, E., 2013, Prayers and players: Religion and politics in Zimbabwe, Sapes Books, Harare.

Cleveland, J.N., Stockdale, M., Murphy, K.R. \& Gutek, B.A., 1988, Women and men in organisations: Sex and gender issues at work, Lawrence Elbaum Associates, Mahwah, New Jersery.

Connel, R.W., 2000, The Men and The Boys, University of California Press, Berkeley.

Dekker, E. \& Lemmer, E.M., 1993, Critical Issues in Modern Education, Butterworths, Durban.

Dube, M., 1990, 'Mary as our ancestor: An African Feminist search for identity', Masters dissertation, Durham University.

Dube, M., 2003, Culture, gender and HIV/Aids: Understanding and acting on the issues, HIV/Aids and the curriculum methods of integrating HIV/Aids in Theological curriculum, pp. 84-100, World Council of Churches, Geneva.

Goebel, A., 2005, 'Zimbabwe fast track land reform: What about women', Gender, Place \& Culture 12(2), 145-172. https://doi.org/10.1080/09663690500094799

Haralambos, M. \& Holborn, M., 2004, Sociology; Themes and perspectives, Harper and Collins, London.

Hodgson, D.L. \& McCurdy, M.A., 2001, 'Wicked' women and the reconstruction of gender in Africa, Heinemann Press, Portsmouth.

Maloba, W.O., 2007, African women in revolution, African World Press, New Jersey.

Matondi, P.B., 2012, Zimbabwe's fast track land reform, Zed Books, London.

Mukonyora, I., 2007, Wandering a gendered wilderness: Suffering and healing in an African initiated Church, Peter Lang Publishing, New York.

Oduyoye, M.A., 1995, Daughters of Anowa: African women and patriarchy, Orbis Books, Mary Knoll, Cambridge University Press, Cambridge.

Parpart, J.I., Connelly, M.P. \& Barriteau, V.E., 2000, Theoretical perspective on gender and development, International Development Research Center, Ottawa.

Sifuniso, M., Kasonde, C., Kamani, E.N., Maimbolwa-Sinyangwe, I., Kimani, C. \& Nalumango, M., 2000, Gender-Sensitive Editing (Perspectives on African book development), Adea Department for International Development, United Kingdom.

Sawayer, D., 1995, 'Fewell, Dana Nolan, and Gunn, David M., Gender, Power, and Promise: The Subject of the Bible's First Story', Theology \& Sexuality, 2, 118-119. https://doi.org/10.1177/135583589500100209

Staunton, V., 1991, Gillian: A second chance, Blackwater Press, Dublin.

Tamez, E., 1989, 'Now no condemnation: A meditation on Romans 8', The Ecumenical Review, 41(3);446-453. https://doi.org/10.1111/j.1758-6623.1989.tb02597.x

Vellem, V.S., 2016, Epistemological dialogues as Prophetic: A Black Theological perspective on the land issue, University of Pretoria, Pretoria.

Vengeyi, O., 2013, Aluta Continua Biblical hermeneutics for liberation: interpreting Biblical texts on slavery for liberation of Zimbabwean underclasses. University Press, Bamberg.

Walby, S. (ed.), 1999, Inequality beyond globalisation: Economic changes, social transformations, Routledge, London.

Zvayi, C., 2016, Scaling Mount Nyangani to be heard, viewed 13 October 2019 from https://www.herald.co.zw/scaling-mt-nyangani-to-be-heard/. 